\title{
Nutritional Status of Lacto-ovo Vegetarian Young Adults of Babcock University in Ogun State
}

\author{
Ngozi Elizabeth $0^{1^{*}}$, Onabanjo Oluseye $\mathbf{0}^{2}$, Akinlade Ademola $\mathbf{R}^{3}$, Adeoye Bolade $\mathbf{K}^{4}$, Ani Ime $\mathrm{F}^{5}$ \\ ${ }^{2}$ Department of Nutrition and Dietetics Federal University of Agriculture Abeokuta, Ogun State, Nigeria \\ 1,3,4,5 Department of Nutrition and Dietetics, Ben Carson Snr School of Medicine and Surgery, Babcock University, Ilishan-Remo, Ogun \\ State, Nigeria
}

\begin{abstract}
Received: February 01, 2018; Accepted: April 4, 2018; Published: April 18, 2018
*Corresponding author: Ngozi Elizabeth Oluwafunmiso, Department of Nutrition and Dietetics, Ben Carson Snr School of Medicine, Babcock University, Ilishan-Remo, Ogun State, Nigeria, E-mail:ngozie@babcock.edu.ng
\end{abstract}

\begin{abstract}
Nutritional status is globally recognized as the means of determining the body's nutritional health. Several research findings had shown that there is an increasing rate of malnutrition as well as obesity across the globe. The practice of vegetarianism is recognized as one of the mechanism through which good nutritional status could be maintained. As nutritional health of adolescents and young adults most of whom are at the age of undergraduate studies has been acknowledged as being very important for supporting their growing bodies as well as prevent future health problems; many of them are reported to be engaging in habits that affect their nutritional health. The study therefore investigated the nutritional status of lacto-ovo vegetarian young adults of Babcock University, Ogun State, Nigeria. The study carried at Babcock University, Ilishan Remo Ogun State, Nigeria utilized a sample of 210 students. Samples of each cooked food served to the students were collected for each meal served during the whole week. Nutritional status of the respondents and the data from anthropometry measurements indicates that $67.59 \%$ were normal, $18.52 \%$ over-weight, $11.11 \%$ obese and $2.77 \%$ were underweight. Majority (70.41\%) of the female respondents was Normal, $18.37 \%$ were overweight, and $9.18 \%$ were obese while $2.04 \%$ were underweight. From the overall nutritional status of the respondents based on Body Mass Index (BMI), majority (68.93\%) of the respondents were normal, $18.45 \%$ were overweight and $10.19 \%$ of the respondents were obese while $2.43 \%$ were underweight. percentage of respondents that were below or above the Recommended Dietary Intake (RDI). For Energy, only $2 \%$ of the respondents were above the RDI, $97.1 \%$ were above protein RDI, $3 \%$ were above Iron RDI while the entire respondents were below the RDI for Calcium and Zinc.
\end{abstract}

\section{Introduction}

Adolescence is the transition period between childhood and adulthood, a time of life that begins at puberty. For girls, puberty typically occurs between ages 12 and 13, while for boys it occurs between ages 14 and 15. It is one of the fastest growth periods of a person's life. The whole period of adolescence is from 13 to 17 years of age. Vegetarians tend to have lower Body Mass Index (BMI), type 2 diabetes, Iron deficiency anaemia, renal disease, osteoporosis, dementias such as Alzheimer's disease and other disorders $[21,22]$. The physical changes of adolescence have a direct influence on a person's nutritional needs. Teenagers need additional calories, protein, calcium, and iron [11].
Vegetarianism is the practice of following a plant - based diet including fruits, vegetables, cereals, grains, nuts and seeds with or without dairy products and eggs. A vegetarian does not eat meat including: red meat, game, poultry, fish, crustacean, shellfish and products of animal slaughter such as animal derived gelatin and rennet [18]. Vegetarianism is considered a healthy viable diet. The American Dietetic Association and the Dietitians of Canada have found a properly planned vegetarian diet to satisfy the nutritional needs for all stages of life and large scale studies have shown that "mortality from ischemic heart disease was $24 \%$ lower in vegetarians than in non vegetarians [12].

"Vegetarian dietary patterns are quite diverse and variant due to food availability, region, age, gustatory reasons and religion and cultural beliefs. They encompass a wide range of plant products and food practices based on these factors and always begin with a plant based foundation" [1].

There is evidence that well-planned vegetarian diet provides numerous health benefits and is appropriate for all stages of life cycle [10]. Considering health hazards of consumption of protein rich diet deriving from animal sources, proportion of vegetarian or people consuming vegetable-based diet is increasing globally $[6,9,13,14]$.

Lacto-ovo vegetarians are allowed the consumption of milk which is a good source of calcium. However, Lacto-ovovegetarians, who consume diets which are generous in dairy products, should be advised to eat substantial amounts of ironrich vegetables, grains, and legumes to minimize the inhibitory effect of calcium, and also to consume plenty of vitamin C-rich fruits to facilitate absorption of the non-heme iron. Vitamin $\mathrm{C}$ appears to enhance iron retention when calcium is consumed in the same meal [8].

There is a need to detect under nutrition in individuals and to assess the severity of the problem in the community [17]. The use of nutritional anthropometric measure serves as an indicator of under nourishment. Nutritional anthropometry addresses issues related to reference values and discusses cut offs based on relationship between functional impairment, morbidity and other consequences of food inadequacy. Since diet is a component of 
health that can be modified fairly readily and specific nutritional guidance can be given to people to ensure adequate nutrition [19].

Studies have shown that adolescents who are vegetarians often engage in disturbed eating $[4,15]$. Adolescents and young adults were found to be more likely to engage in binge eating with loss of control. However, that is there is no agreement on whether vegetarianism is the cause of disordered eating or whether is the manifestations of disordered eating (causal-symptomatic relationship) [1].

The concept that a well-balanced vegetarian diet can provide for the needs of a growing child and adolescent is supported by Canada's Food Guide, the American Dietetic Association and Dietitians of Canada, and the American Academy of Pediatrics [23]. A review of vegetarian diets based on ten studies found that vegetarians had lower intake than omnivores for only a few nutrients: vitamins B12 and C, calcium and zinc [7]. Overall conclusions were that vegetarian diets can be nutritionally adequate. Any nutritional deficits can be addressed by taking supplements, eating fortified foods, or preparing and combining foods to enhance absorption of vitamins and minerals [2]. The study therefore examined the nutritional status of Lacto-ovo vegetarian young adults of Babcock University in Ogun State.

\section{Materials and Methods}

\section{Sample and Sampling Technique}

The Study population comprised male and female students of Babcock University. According to the University records of 2015/2016 session, Babcock University had a student population of six thousand one hundred and ninety eight students $(6,198)$ out of which five thousand five hundred and seventy four $(5,574)$ were boarders.

The sample size for the study was calculated using [3].

$\mathrm{N}=2(\mathrm{Za})^{2} \mathrm{pq} / \mathrm{d}^{2}$

Where $\mathrm{N}=$ sample size

$(\mathrm{Za})^{2}=$ level of confidence or the probability that the true percentage is within chosen value $d=1.96$

$\mathrm{P}=$ proportion or estimate of percentage of sampling frame.

$q=100-p$

$\mathrm{d}=$ level of precision $(5 \%)$ required of results.

Hence, 210 student sample size at $5 \%$ level of precision was obtained. This study therefore used 210 boarding students as respondents for this study.

Two hundred and ten (210) healthy students were randomly selected for the study but Two hundred and six (206) questionnaires with matching anthropometry measurement and food intake were analyzed

\section{Data Collection}

The data were collected using semi-structured questionnaire.
The questionnaire has information on (personal data, socioeconomic and demographic, physical activities, dietary and food intake pattern, and 24-hour dietary recall). Self administered questionnaire written in English was administered to selected respondents.

Data were collected in the following ways:

\section{Anthropometry Measurements}

\section{a) Weight Measurement}

Body weights were measured using bathroom scale. The scale was placed on a flat surface and the subjects were made to stand uprightly, barefooted, with minimum clothing. The reading was done in duplicate to the nearest $0.1 \mathrm{~kg}$ and the average weight was calculated.

\section{b) Height measurement}

Height measuring scale was used to measure the individual heights. The subjects were made to stand erect on the base place without shoes, socks, head tie in order to give accurate distance between the sole of the feet and the crown of the head. As the subjects are looking straight, the head piece was sliced down to the head crown. The heights was taken to the nearest $0.1 \mathrm{~m}$ and repeated to obtain the average value.

\section{C) Body Mass Index (BMI)}

This was determined by dividing the weight of each respondent in kilogram by the square of his height in meters (World Health Organization, 2009).

$$
\mathrm{BMI}=\frac{\text { Weight }(\mathrm{Kg})}{(\text { Height })^{2}\left(\mathrm{~m}^{2}\right)}
$$

\section{Weighed Food Intake}

All food taken by all respondents from the school cafeteria were measured. They were measured using a kitchen scale calibrated from 0 to $5 \mathrm{~kg}$ to get the quantity of food intake. The quantity taken and plate waste were measured on a three day basis (one weekend day and two week days) per respondents.

\section{Data Analysis}

The data were scrutinized, cleaned, and then entered into the computer, for analysis using SPSS, version 20.0. The data generated were analyzed using descriptive statistics such as means, standard deviations, percentages and frequencies of respondent's characteristics. The differences between male and female respondents were determined using student's t-test.

\section{Results}

\section{Respondents Personal Data}

Table 1, shows the students' personal data, the ages of the students ranged from 16 to 25 years and above. Some (40.3\%) were $16-20$ years of age, $46.1 \%$ were $21-25$ years of age while $13.6 \%$ were above 25 years of age. The mean age however was between $2 \mathrm{l}-25$ years. Over half $(52.43 \%)$ of the respondents were male. Majority (85.4\%) of the respondents was single, 
Nutritional Status of Lacto-ovo Vegetarian Young Adults of Babcock University in Ogun State

Table 1: Students personal data

\begin{tabular}{|c|c|c|}
\hline Age range (years) & Frequency (no) & Percentage (\%) \\
\hline $16-20$ & 83 & 40.3 \\
\hline $21-25$ & 95 & 46.1 \\
\hline$>25$ & 28 & 13.6 \\
\hline Total & 206 & 100 \\
\hline \multicolumn{3}{|l|}{ Sex } \\
\hline Male & 108 & 52.43 \\
\hline Female & 98 & 47.57 \\
\hline Total & 206 & 100 \\
\hline \multicolumn{3}{|l|}{ Marital Status } \\
\hline Single & 176 & 85.4 \\
\hline Married & 29 & 14.1 \\
\hline Widow & 1 & 0.5 \\
\hline Total & 206 & 100 \\
\hline \multicolumn{3}{|c|}{ Religious Affiliation } \\
\hline Christianity & 147 & 71.4 \\
\hline Islamic & 47 & 22.8 \\
\hline Traditional & 12 & 5.8 \\
\hline Total & 206 & 100 \\
\hline \multicolumn{3}{|l|}{ Tribe } \\
\hline Yoruba & 84 & 41.78 \\
\hline Hausa & 46 & 22.33 \\
\hline Igbo & 63 & 30.58 \\
\hline Minority & 13 & 6.31 \\
\hline Total & 206 & 100 \\
\hline \multicolumn{3}{|l|}{ Family Type } \\
\hline Monogamous & 179 & 86.89 \\
\hline Polygamous & 27 & 13.11 \\
\hline Total & 206 & 100 \\
\hline
\end{tabular}

$14.1 \%$ were married, and $0.5 \%$ were widows. About $71 \%$ were Christians, 22.8\% were Muslims, while 5.8\% were traditionalists. About $42 \%$ of the respondents were Yoruba, $30.58 \%$ were Ibo, $22.33 \%$ Hausa and $6.31 \%$ were from the minority ethnic groups. Majority $(86.89 \%)$ of the students were from monogamous families, while $13.11 \%$ were from polygamous families.

Table 2 below shows the nutritional status of the respondents and the data indicates that $67.59 \%$ were normal, $18.52 \%$ over-weight, $11.11 \%$ obese and $2.77 \%$ were underweight. Majority $(70.41 \%)$ of the female respondents was Normal, $18.37 \%$ were overweight, and $9.18 \%$ were obese while $2.04 \%$ were underweight. From the overall nutritional status of the respondents based on Body Mass Index (BMI), majority (68.93\%) of the respondents were normal, $18.45 \%$ were overweight and $10.19 \%$ of the respondents were obese while $2.43 \%$ were underweight.

\begin{tabular}{|c|c|c|}
\hline Status & $\begin{array}{c}\text { Frequency } \\
\text { (no) }\end{array}$ & $\begin{array}{c}\text { Percentage } \\
\text { (\%) }\end{array}$ \\
\hline \multicolumn{3}{|l|}{ Male Respondents } \\
\hline Under-weight & 3 & 2.77 \\
\hline Normal & 73 & 67.59 \\
\hline Over-weight & 20 & 18.52 \\
\hline Obese & 12 & 11.11 \\
\hline Total & 108 & 100 \\
\hline \multicolumn{3}{|l|}{ Female Respondents } \\
\hline Underweight & 2 & 2.04 \\
\hline Normal & 69 & 70.41 \\
\hline Overweight & 18 & 18.37 \\
\hline Obese & 9 & 9.18 \\
\hline Total & 98 & 100 \\
\hline \multicolumn{3}{|l|}{ Total status } \\
\hline Underweight $\left(<18.5 \mathrm{~kg} / \mathrm{m}^{2}\right)$ & 5 & 2.43 \\
\hline Normal $\left(8.5-24.9 \mathrm{~kg} / \mathrm{m}^{2}\right)$ & 142 & 68.93 \\
\hline Overweight $\left(25.0-29.9 \mathrm{~kg} / \mathrm{m}^{2}\right)$ & 38 & 18.45 \\
\hline Obese $\left(>30 \mathrm{~kg} / \mathrm{m}^{2}\right)$ & 21 & 10.19 \\
\hline Total & 206 & 100 \\
\hline
\end{tabular}

\section{Food Intake of Respondents}

Table 3, shows account of the nutrient based on the food intake of the respondents. Only the protein intake was within the range of Male and Female Recommended Dietary Intakes (RDI). The Energy, Calcium, Iron and Zinc intake were below the RDI. However, considering the fact that respondents are vegans, the intake levels were moderate.

In table 4, The RDI of Nutrients covered by the meal consumed by the Male and Female respondents is shown. The Female covered $114.26 \%$ of the protein RDI while the Male covered $84.28 \%$ of the RDI which were significantly different. The Energy intake of the Male was $73.36 \%$ of RDI while that of the Female was $96.27 \%$ of RDI. The Calcium intake for both Male and Female covered $47.60 \%$ and $48.55 \%$ respectively. The Male Iron intake covered $65.40 \%$ and the Female Iron intake covered 39.33\% while the Male intake of Zinc covered $43.20 \%$, the Female intake of Zinc covered 54.83\%. Generally, the Energy, Calcium, Iron and Zinc intake were not significantly different from Male to Female.

Table 5, gives the percentage of respondents that were below or above the Recommended Dietary Intake (RDI). For Energy, only $2 \%$ of the respondents were above the RDI, $97.1 \%$ were above protein RDI, $3 \%$ were above Iron RDI while the entire respondents were below the RDI for Calcium and Zinc. 
Nutritional Status of Lacto-ovo Vegetarian Young Adults of Babcock University in Ogun State

Table 3: Nutrient intake of respondents

\begin{tabular}{|c|c|c|c|}
\hline \multirow[b]{2}{*}{ Nutrient } & \multirow[t]{2}{*}{ Intake } & \multicolumn{2}{|c|}{ RDI } \\
\hline & & Male & Female \\
\hline Energy (Kcal) & $2118.75 \pm 89.22$ & 2900 & 2200 \\
\hline Protein (g/day) & $50.68 \pm 6.63$ & 58 & 46 \\
\hline Calcium (mg) & $573.97 \pm 178.69$ & 1200 & 1200 \\
\hline Iron (mg) & $6.22 \pm 2.07$ & 10 & 15 \\
\hline Zinc (mg) & $6.51 \pm 3.36$ & 15 & 12 \\
\hline
\end{tabular}

Table 4: The Mean and Percentage Nutrient Intake by Sex

\begin{tabular}{|c|c|c|c|c|c|}
\hline Nutrient & Sex & Mean & $\%$ of RDI & T-Value & Sig \\
\hline & Female & 52.56 & 114.26 & 2.53 & \\
\hline \multirow[t]{2}{*}{ Protein } & Male & 48.88 & 84.28 & 1.39 & $0.01^{*}$ \\
\hline & Female & 2118 & 96.27 & 0.34 & \\
\hline \multirow[t]{2}{*}{ Energy } & Male & 2139 & 73.36 & 0.28 & $0.05^{*}$ \\
\hline & Female & 582.6 & 48.55 & 23.66 & \\
\hline \multirow[t]{2}{*}{ Calcium } & Male & 571.2 & 47.6 & 28.07 & $0.01^{*}$ \\
\hline & Female & 5.9 & 39.33 & 21.27 & \\
\hline \multirow[t]{2}{*}{ Iron } & Male & 6.54 & 65.4 & 17.34 & $0.01^{*}$ \\
\hline & Female & 6.58 & 54.83 & 26.77 & \\
\hline Zinc & Male & 6.48 & 43.2 & 32.32 & $0.01^{*}$ \\
\hline
\end{tabular}

Table 5: Percentage of respondents below or above RDI

\begin{tabular}{|c|c|c|}
\hline Nutrients & \% Below RDI & \% Above RDI \\
\hline Energy & 98 & 2 \\
\hline Protein & 2.9 & 97.1 \\
\hline Calcium & 100 & 0 \\
\hline Iron & 97 & 3 \\
\hline Zinc & 100 & 0 \\
\hline
\end{tabular}

\section{Discussion}

The study population was mostly Christians from monogamous family with a mean age of 21-25 years of age which is the age group for most university undergraduates. Most of the respondents were Yoruba given that Babcock University is located in the southwest, a Yoruba speaking geopolitical zone of Nigeria. The parents of the respondents were mainly from the literate class with post graduate education and high income earning who could afford the cost of a private university education.

The Nutritional status of the respondents showed that majority of them was normal while a few were either underweight or obese. When separated by sex, male and female respondents were similar and the values close. The low activity pattern of the students may have resulted in the few obese respondents since a positive energy balance was recorded even when their nutrient intake was below RDI.

The results of this study showed that the nutrient intake of these students needs to be increased to meet the nutrient requirements of male and female students. Hence, the findings of this research support which says that vegans may need guidance on appropriate diet planning and food selection in order to achieve an adequate intake of bioavailable Iron and Zinc [23].

\section{Conclusion}

The nutritional status of the respondents showed that over $50 \%$ of the study population was normal, although the nutrient intake of the respondents was generally below the RDI. The activity level of the respondents in relation to their energy intake gave a positive energy balance, which could be attributed to the high energy content of the breakfast meals.

\section{Recommendations}

Foods that will give higher or additional nutrient to the student should be included in their daily meals thus adjusting the menu to support more intakes of the nutrients. Different varieties of fruits should be served with each meal, to improve on the nutritional status of the young adults.

Further studies on the nutritional status and a comparative study of pure vegans, Lacto-ovo vegetarians, non vegans could be carried out.

\section{References}

1. Melina V, Craig W, Levin S. Position of Academy of Nutrition and Dietetics: Vegetarian Diet. J Acad Nutr Diet. 2016;116(12):1970-1980. doi: 10.1016/j.jand.2016.09.025

2. Akther, F Akther, MKSen, BK Rahman, M Talukder MU. Assessment of Nutritional Status \& Health Condition Among Vegetarian and Non-vegetarian Adult at Tangail Sadar Upazila in Tangail District. International Journal of Nutrition and Food Sciences. 2016;5(4):241245 .

3. Araoye NA. Research Methodology with Statistics for Health and Social Sciences, Ilorin, Nigeria. 2003;Mathadex Publishers.

4. Bardone-Cone AM, Fitzsimmons-Craft EE, Harney MB, Maldonado CR, Lawson MA, Smith R, et al. The inter-relationships between vegetarianism and eating disorders among females. J Acad Nutr Diet. 2012;112(8):1247-1252. doi: 10.1016/j.jand.2012.05.007

5. Craig WJ. Phytochemicals: Guardians of our health. J Am Diet Assoc. 1997; 97: S199-S204.

6. Craig WJ. Health effects of vegan diets. American Journal Clinical Nutrition. 2009;89(5):1627S-1633S.

7. Craig W, Mangels AR. Position of the American Dietetic Association: Vegetarian Diets. J Am Diet Assoc. 2009;109 (7):1266-1282. 
8. Deehr MS, Dallal GE, Smith KT, et al. Effects of different calcium sources on iron absorption in postmenopausal women. Am J Clin Nutr. 1990;51(1):95-99.

9. Dunham L and LM Kollar. Vegetarian eating for children and adolescents. J Pediatr Health Care. 2006;20(1):27-34.

10.Elmadfa I, I Singer. Vitamin B-12 and homocysteine status among vegetarians: a global perspective. Am J Clin Nutr. 2009;89(5):1693S-1698S. doi: 10.3945/ajcn.2009.26736Y

11. Hallberg L, Rossander L. Improvement of iron nutrition in developing countries: Comparison of adding meat, soy protein, ascorbic acid, citric acid, and ferrous sulphates on iron absorption from a simple Latin American - type of meal. Am J Clin Nutr. 1984;39(4): 577- 583.

12. Timothy J Key, Paul N Appleby, Gwyneth K Davey, Naomi E Allen, Elizabeth A Spencer, Ruth C Travis. Mortality in British vegetarians: review and preliminary results from EPIC - Oxford. American journal of Clinical Nutrition. 2003;78(3):5335-5386.

13. Nakamoto Ketal. A new Japanese vegetarian food guide. Asia PacJPublic Health. 2009; 21(2):160-169. doi: 10.1177/1010539509331595.

14. Povey R, B Wellens, M Conner. Attitudes towards following meat, vegetarian and vegan diets: an examination of the role of ambivalence. Appetite. 2001;37(1): 15-26.
15. Robinson-O’Brien R, Perry CL, Wall MM, Story M, Neumark-Sztainer D. Adolescent and young Adult vegetarianism: Better dietary intake and weight outcomes but increased risk of disordered behaviours. J Am Diet Assoc. 2009;109(4):648-655. doi: 10.1016/j.jada.2008.12.014

16.Sandstrom B. Bioavailability of zinc. European Journal Clinical Nutrition. 1997;51:S17-S19.

17. Shetty P. Measures of nutritional status from anthropometric survey data. 2009

18. The Vegetarian Society. "The Vegetarian society - definitions information sheet". 2008.

19. Wong EK, Enomoto H, Leopold IH, Williams JL, Kladde L, Hollander DH. Intestinal absorption of dietary fat in patients with multiple Sclerosis. Metab Pediatric Syst ophthamol. 1993;16(3-4):39-42.

20. World Health Organization. Facts on obesity and overweight. 2009; WHO.

21. Mattson, Mark P. Diet-Brain Connection: Impact on memory, mood, aging and disease. 2002; Kluwer Academic Press

22. Americanheart.org (AHO) (2009) "Vegetsrian Diets"

23. Sandstrom B. Bioavailability of Zinc. European Journal Clinican Nutrition; 1997;51:S17-S19.

24. World Health Organization (WHO), (2009). Diet, physical activity and health, WHASS 23, Geneva:WHO. 